\title{
9
}

\section{FISHING FOR A FUTURE}

\author{
Hannah Parris and R. Quentin Grafton
}

The development challenges facing the countries of the southern central and western Pacific Ocean (collectively Melanesia, Polynesia and Micronesia—or Pacific island countries) are daunting despite substantial in flows of development assistance. ${ }^{1}$ The difficulties facing these countries include the unsustainable use of key resources, such as fisheries, high rates of unemployment and underemployment, low levels of economic growth and, in some countries, social unrest and political instability (World Bank 2000b; Asian Development Bank 2004). To help address these concerns, Pacific island countries have embraced the sustainable development agenda and are active participants in a variety of fora, including the Barbados Plan of Action for Small Island Developing States. In the forefront of the development agenda of many Pacific island countries is how to utilise the region's natural resources—such as, fisheries, forests and tourist potential - to promote both social and economic goals.

In this chapter, we focus on the western and central Pacific region's highly prized fish stocks, found in the exclusive economic zones of Pacific island countries, and in the high seas in between, and how they might be used to sustain development. In section two, we briefly review broad measures of wellbeing and economic performance of Pacific island countries, and describe the importance of the tuna fisheries and the challenges faced by the region's countries. Section three highlights the major challenges to cooperatively managing tuna resources to maximise the benefits to the island states. In 
particular, we examine whether the recent 'Convention on the Conservation and Management of Highly Migratory Fish Stocks in the Western and Central Pacific Ocean' (hereafter the 'Tuna Convention') can deliver the potential benefits of cooperation. Later, we examine other constraints-in particular the quality and capacity of public institutions - that prevent Pacific island countries from making the best use of the resource rents from their tuna fisheries. We conclude by proposing two approaches that Pacific island countries, with assistance from donor countries, may wish to consider to sustain the region's development.

\section{TUNA-LED SUSTAINABLE DEVELOPMENT IN PACIFIC ISLAND COUNTRIES}

Income levels in the Pacific region are low by world standards, but there is substantial variability among countries. Table 9.1 indicates that only one country, Palau, has an upper middle level of income, and all others fall in the lower half of the world's countries in terms of their 'Human Development Ranking'. ${ }^{2}$ Some countries have also experienced negative economic growth in the recent past, and many Pacific island countries have the challenge of ensuring rising living standards in the face of rapid increases in population.

Although the 14 independent countries and the eight dependent territories that constitute the region have very small populations (only Papua New Guinea has a population greater than one million), their exclusive economic zones extend 200 nautical miles from land and represent a huge area of the Pacific Ocean. Not surprisingly, marine resources are critically important to the wellbeing of some Pacific island countries, especially those with a large exclusive economic zone, a small population and a tiny land mass. In the case of the Federated States of Micronesia and Kiribati, the value of fish caught in their exclusive economic zones exceeds their gross national income, while in the Marshall Islands and Solomon Islands it almost equals their national income. Pacific island countries, however, receive only a tiny fraction of the benefits from the fisheries found in their territories because about 90 per cent of the fish caught in their exclusive economic zones are harvested by 'distant water fishing nations', and these nations only pay approximately 3-4 per cent of the landed value in access fees (Petersen 2005).

The failure to realise fully the potential benefits from their fishery resources is of major concern for Pacific island countries. Many thought that the Pacific 
islands countries would experience an economic 'bonanza' on being granted exclusive economic zones under the third United Nations Convention on the Law of the Sea. ${ }^{3}$ It was hoped that fisheries would address two major challenges: reduce the risks of overexploitation of a common-pool resource and provide the Pacific island countries with a reliable source of income with which to finance economic development (Chand et al. 2003). Whatever exclusive economic zones may have delivered to Pacific island countries, they have coincided with a substantial increase in fishing effort and harvests. For instance, Figure 9.1 shows that the total harvest of tuna has more than doubled since the 1980s, and the region now supplies about 40 per cent of the world's global catch of tuna. The latest data suggest that catches of some tuna in the region may have peaked, such as yellowfin tuna, and that some stocks, such as bigeye tuna, may even be overexploited (Langley et al. 2005). Another worrying trend has been a 70 per cent decline in the catch per unit of effort of yellowfin tuna in the western Pacific over the past 50 years, although exactly what this implies about overall tuna populations is disputed (Hampton et al. 2005; Myers and Worm 2005).

Table 9.1 Development and fishery statistics of selected Pacific island countries

\begin{tabular}{|c|c|c|c|c|c|c|c|}
\hline & $\begin{array}{l}\text { Population } \\
\left({ }^{\prime} 000\right)^{a}\end{array}$ & $\begin{array}{c}\text { Annual } \\
\text { population } \\
\text { growth } \\
1990-98\end{array}$ & $\begin{array}{c}\text { GNI per } \\
\text { capita } \\
(\text { US\$) }\end{array}$ & $\begin{array}{l}\text { Mean gross } \\
\text { fisheries } \\
\text { revenues } \\
1993-98 \\
(\% \text { of GNI })^{a}\end{array}$ & $\begin{array}{l}\text { Adult } \\
\text { literacy }\end{array}$ & $\begin{array}{l}\text { Life } \\
\text { expectancy } \\
\text { at birth }\end{array}$ & $\begin{array}{c}\text { Global } \\
\text { HDI } \\
\text { rank }\end{array}$ \\
\hline FSM & 120 & 2.1 & 2,150 & 215 & 71.3 & 65.7 & 120 \\
\hline Fiji & 824 & 0.9 & 2,130 & - & 92.9 & 66.6 & 101 \\
\hline Kiribati & 93 & 2.1 & 830 & 503 & 92.2 & 61.6 & 129 \\
\hline Marshall Islands & 53 & 3.6 & 2,190 & 85 & 74.4 & 65.0 & 121 \\
\hline Palau & 20 & 2.4 & 6,730 & 5 & 91.4 & 69.0 & 46 \\
\hline Tonga & 101 & 0.3 & 1.530 & - & 99.0 & 68.0 & 107 \\
\hline Samoa & 171 & 1.2 & 1,520 & 6 & 95.7 & 66.6 & 117 \\
\hline Solomon Islands & 432 & 3.3 & 580 & 87 & 30.3 & 64.7 & 147 \\
\hline Vanuatu & 203 & 2.7 & 1,050 & - & 33.5 & 65.8 & 140 \\
\hline
\end{tabular}

Notes: ${ }^{a} 2001$ figures. FSM = Federated States of Micronesia. GNI = gross national income.

Source: World Bank, 2000a. Small States: meeting challenges in the global economy, Commonwealth Secretariat/World Bank Joint Task Force report, London; World Bank, 2003. Sustainable Development in a Dynamic World: transforming institutions, growth, and quality of life, Oxford University Press, New York; Petersen, E.H., 2005. Institutional Economics and Fishery Management, Edward Elgar, Cheltenham (in press); and authors' calculations. 
Most tuna in the region are caught by large purse-seiner vessels worth up to millions of dollars and almost exclusively owned and operated by 'distant water fishing nations'. Of the total landed value of fish in the Western and Central Pacific - approximately US $\$ 2$ billion-only about US\$60 million is paid in access fees to Pacific island countries (Gillett et al. 2001). These access fees are low compared to those paid in other parts of the world (Chand et al. 2003; Inhedru 1995). This is explained, in part, by

- Pacific island countries' lack of bargaining power relative to 'distant water fishing nations'

- provisions imposed on 'distant water fishing nations'- such as transhipment of fish (Duncan and Temu 1997)—that reduce returns to fishing

- the linking of development aid and assistance with access fees

- current fishing effort seemingly exceeding the economic surplus maximising level (Bertignac et al. 2000).

Figure 9.1 The volume of tuna resources harvested in the Western and Central Pacific, 1950-2003

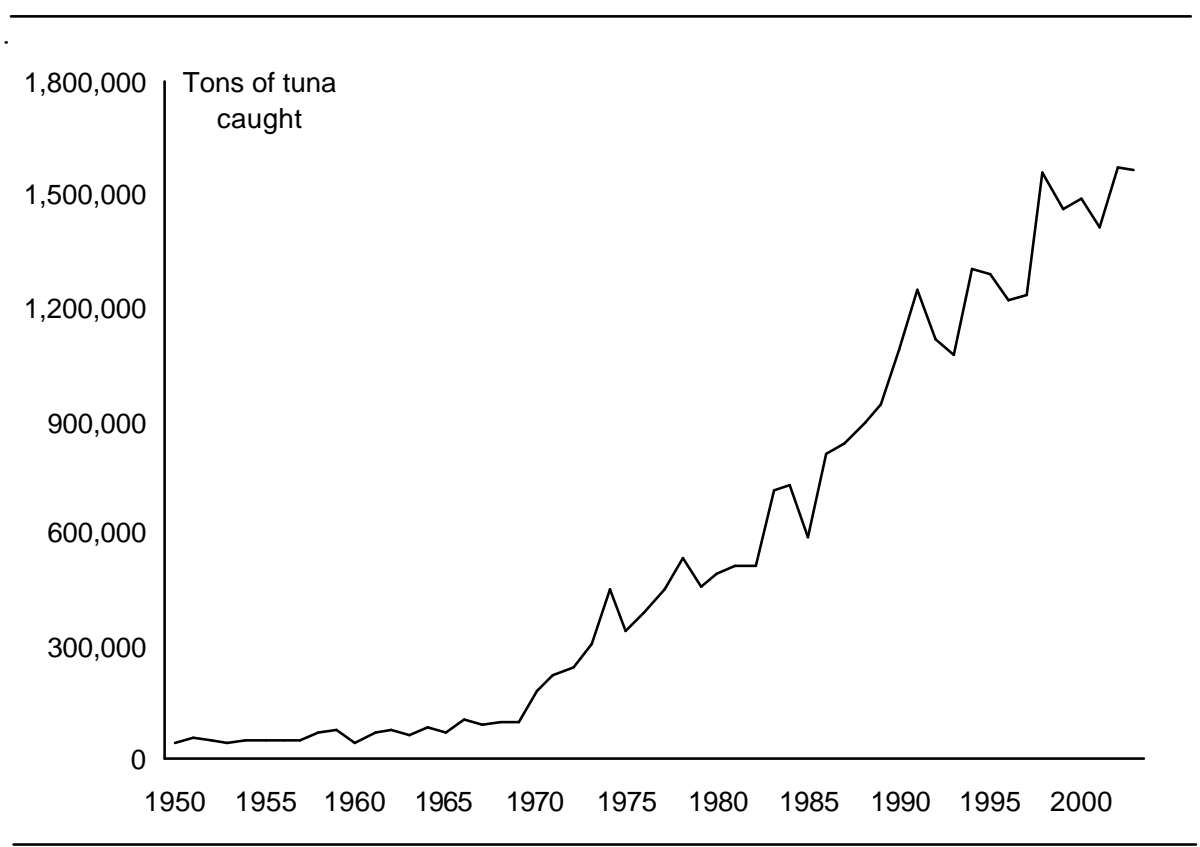

Source: Food and Agriculture Organization, 2005. Total Production 1950-2003, Fishstat Dataset, FAO, Rome. 


\section{2 \\ Pacific Island Regional Integration and Governance}

\section{Bargaining power}

Pacific island countries' initial attempts to gain reasonable access to resource rents accruing from their fisheries were hampered by their negotiation experiences with the Japanese, who in the early 1980s harvested about threequarters of the tuna stocks. Moreover, relatively unsuccessful experiments with multilateralism in other areas, such as air transport, in the 1970s (Fry 2005) left some Pacific island countries reluctant to collaborate and bargain as a group. This made it easier for the Japanese to manipulate negotiations through a 'divide and conquer' strategy. By refusing to negotiate with Pacific island countries collectively, and ensuring that at least one access arrangement to an exclusive economic zone was always in operation, the Japanese were able to keep Pacific island countries in competitive positions with respect to one another (Schurman 1998). This strategy was enhanced by the fact that the benefits and costs to Pacific island countries of implementing collective bargaining are likely to be unevenly distributed, thus lowering the incentive for these countries to form cooperative arrangements.

It appears that Pacific island countries have become more adept in bargaining with 'distant water fishing nations' over time and have realised the benefits of cooperating in discussions of access. For example, the formation of the Nauru, Palau and Federated States of Micronesia agreements represent successful efforts at coordination, although these agreements only explicitly cover licensing conditions. In addition, the Nauru Group appears to have improved access agreements and payoffs to Pacific states (Munro et al. 2004), and Japan seems increasingly receptive to discussing a multilateral agreement with Pacific island countries. Over time, Japan's relative importance has also diminished (see Table 9.2) in the face of increased access and competition by the Taiwanese, Korean, Chinese and US fleets, forcing the Japanese to concede to more reasonable access fees (Schurman 1998; Petersen 2005). Unfortunately, increased harvests from the new entrants appear also to have reduced overall returns and the ability of 'distant water fishing nations' to pay increased access fees.

\section{Bundling of aid and fisheries access}

It is common practice in the Pacific for donors to bundle in-kind or financial development assistance in the expectation that they will be favourably considered in negotiations over access to resources and fees. Schurman (1998) cites the example of the National Fisheries Corporation of the Federated States 
of Micronesia receiving 'gifts' of training boats, while the Asian Development Bank observes that almost half of the 'access fees' paid by US boats actually takes the form of development aid (Duncan et al. 1999). Given the secrecy surrounding the bilateral access arrangements it is difficult to determine the extent of this practice, but it does appear to have reduced the access fees paid to Pacific island countries.

\section{Fostering a domestic and commercially competitive fishing industry}

Many Pacific island countries have pursued 'domestication'-developing and/ or then integrating domestically located harvesting and processing sectors to serve export markets - to extract more of the economic benefits from their tuna fisheries. This they have encouraged, first, by publicly financing national industrial enterprises to kick-start a domestic tuna industry, and, second, by attaching industry development conditions to the licensing arrangements for 'distant water fishing nations'. Typically, this second approach has seen Pacific island countries requiring foreign vessels to use domestic infrastructure and/or use nationals to crew boats, as well as maintaining and completing compliance procedures such as those set out in the FSM Agreement. ${ }^{4}$ Unfortunately, these strategies have largely failed (Petersen 2002, 2005; Schurman 1998; Chand et al. 2003; van Santen and Muller 2000; Duncan et al. 1999), but some benefits have been generated through direct and indirect employment in the tuna

Table 9.2 Average annual tuna catches in the Western and Central Pacific region for selected countries

\begin{tabular}{lc} 
Country & $\begin{array}{c}\text { Estimated catch } \\
\text { (average 2000-03) }\end{array}$ \\
Japan & 225,567 \\
Taiwan & 282,458 \\
Korea & 190,761 \\
United States & 97,422 \\
Solomon Islands & 19,063 \\
Vanuatu & 9,593 \\
Papua New Guinea & 112,098 \\
Federated States of Micronesia & 22,747 \\
Australia & 1,892 \\
Total & 961,599 \\
\hline
\end{tabular}

Source: FAO, 2005. Total Production 1950-2003, Fishstat Dataset, FAO, Rome; and authors' calculations. 
industry and also through foreign currency earnings (Barclay and Yoshikazu 2000; Gillett et al. 2001).

In general, Pacific island countries have chosen to focus on the harvesting sector in terms of their public sector investment. Unfortunately, the harvesting of tuna generates highly variable revenues, requires large upfront sunk costs and substantial high technical requirements. The high investment costs and the fickle nature of fishing has meant that mistakes have been made that are financially burdensome for some Pacific island countries (Duncan et al. 1999). ${ }^{5}$ The lack of appropriate technical skills domestically has also meant that Pacific island countries have often had to rely on foreign investment partners to implement projects, or enter into partnerships with foreign firms, reducing the potential financial gains from projects. Van Santen and Muller (2000) summarise some of the investments made by three Pacific island countries (Federated States of Micronesia, Fiji and Marshall Islands) in tuna harvesting, which total over US\$70 million a sum in excess of the region's annual access fees. In general, these investments have been made by the public sector and many have failed to yield a positive financial return (Petersen 2005).

Equally important is whether Pacific island countries could receive a greater amount from access fees alone rather than a mix of access fees and an exportorientated domestic industry (assuming the investment by Pacific island countries generates a positive rate of return). The answer depends on the relative cost efficiency of 'distant water fishing nations' (Munro 1979). If 'distant water fishing nations' have lower harvesting costs, as seems likely given their ability to harvest tuna resources profitably and pay access fees, the potential economic surplus is greater than if Pacific island countries were to do the harvesting.

Another consideration for Pacific island countries, in terms of the domestication of their fishing industry, is the very substantial cost associated with fisheries management. In a number of countries outside the region, the costs of fisheries management exceed the potential benefits from the fisheries (Schrank et al. 2003). This suggests that a 'go-it-alone' strategy in terms of harvesting and managing tuna may be a costly exercise generating few, if any, net benefits for Pacific island nations. The question for advocates of 'domestication' is, therefore, what should be the nature of the partnerships between Pacific island countries and 'distant water fishing nations' that will maximise the payoffs to the Pacific states? 


\section{CHALLENGES TO COOPERATION IN THE WESTERN AND CENTRAL PACIFIC}

There are a number of potential payoffs to Pacific island countries from cooperating over the use of their fishery resources. These include better bargaining power in terms of access fees with 'distant water fishing nations' from the current mean level of about 40 per cent of the total rent; ${ }^{6}$ increased resource rent and greater population resilience from moving to lower rates of exploitation that could more than double the resource rent from the fisheries (Bertignac et al. 2000); higher returns from harvesting older age classes of fish and mitigating the 'race to fish' and, finally, better management from economies of scale and scope associated with shared monitoring, enforcement and stock assessments. Pacific island countries and 'distant water fishing nations' could be made better off with cooperation that reduces current harvesting and directs it to older age classes to raise the overall resource rent. Obtaining such an agreement would require that every country be at least as well off with cooperation. Moreover, there would be significant transitional losses in moving to a lower harvest, but the benefits from higher fish stocks would be unevenly distributed among 'distant water fishing nations' and Pacific island countries. Thus, to achieve an agreement, some form of 'side-payments' in terms of harvest rights or monetary compensation would be required from the winners to the losers as well as incentives for all countries to comply with a cooperative agreement. It would also require barriers to entry for new participants or countries that might also wish to benefit from increased returns from cooperation.

Chand et al. (2003) propose a possible way to achieve a cooperative agreement by the creation of a commission, composed of both Pacific island countries and 'distant water fishing nations', that would allocate harvesting rights as a percentage of a total allowable catch denominated by species and area based on exclusive economic zones and historical fishing patterns. These harvesting rights would be transferable and divisible between vessels flagged by the countries that are signatories to the agreement. Other countries could enter the agreement, but would be required to buy or lease harvesting rights to catch tuna legally in the region. Population assessments and monitoring and enforcement would be paid for out of rentals based on the allocated rights, and, because of economies of scope, could significantly reduce overall 
management costs. To give greater transparency to the size of the resource rents in the fisheries, Chand et al. (2003) recommend that a small percentage of the total rights held by all countries would have to be tendered for sale every year and the prices for the rights made available to all parties.

Unfortunately, the Tuna Convention does not incorporate the features recommended by Chand et al. (2003). Nevertheless, the Western and Central Pacific Fisheries Commission (hereafter 'Fisheries Commission'), the secretariat of the Tuna Convention, offers significant changes in terms of how Pacific island countries and 'distant water fishing nations' cooperate. Table 9.3 summarises key features of the Tuna Convention and its ability to deliver on the aspirations of Pacific island countries. Although the Tuna Convention will not, by itself, allow Pacific island countries to achieve the full economic potential offered by their fishery resources, it is a genuine multilateral regime that includes all Pacific island countries and allows for, and encourages full membership for 'distant water fishing nations'. ${ }^{7}$ It also explicitly recognises the importance of sustainability, ecosystem management and interdependencies of tuna management. As with many international treaties, the key to its success is in how its various articles are applied and enforced, and whether resources are sufficient to achieve the treaty's objectives.

The Tuna Convention allows Pacific island countries to maintain full decisionmaking power with respect to their national exclusive economic zones. While this may be understandable from a political point of view, the retention of access fee arrangements by Pacific island countries means that the potential for 'distant water fishing nations' to 'game' the fee negotiations remains, along with the potential to limit the extent to which Pacific island countries can gain financially from the fishery. To this end, the Tuna Convention does little to help Pacific island countries work cooperatively to maximise resource rents at a sustainable level. Thus the Tuna Convention is not an economic treaty as such (it is a treaty about the amount of fish to be caught) and, therefore, does not address the economic/financial issues inherent in resource management. Moreover, the Tuna Convention does not prevent the Pacific island countries from attaching conditions to access and licensing similar to those set out in the Nauru, Palau and Federated States of Micronesia arrangements.

As with all new institutions, the future of the Tuna Convention depends on the strength of its implementation processes. The Fisheries Commission is charged with determining the total allowable catch or total level of fishing 


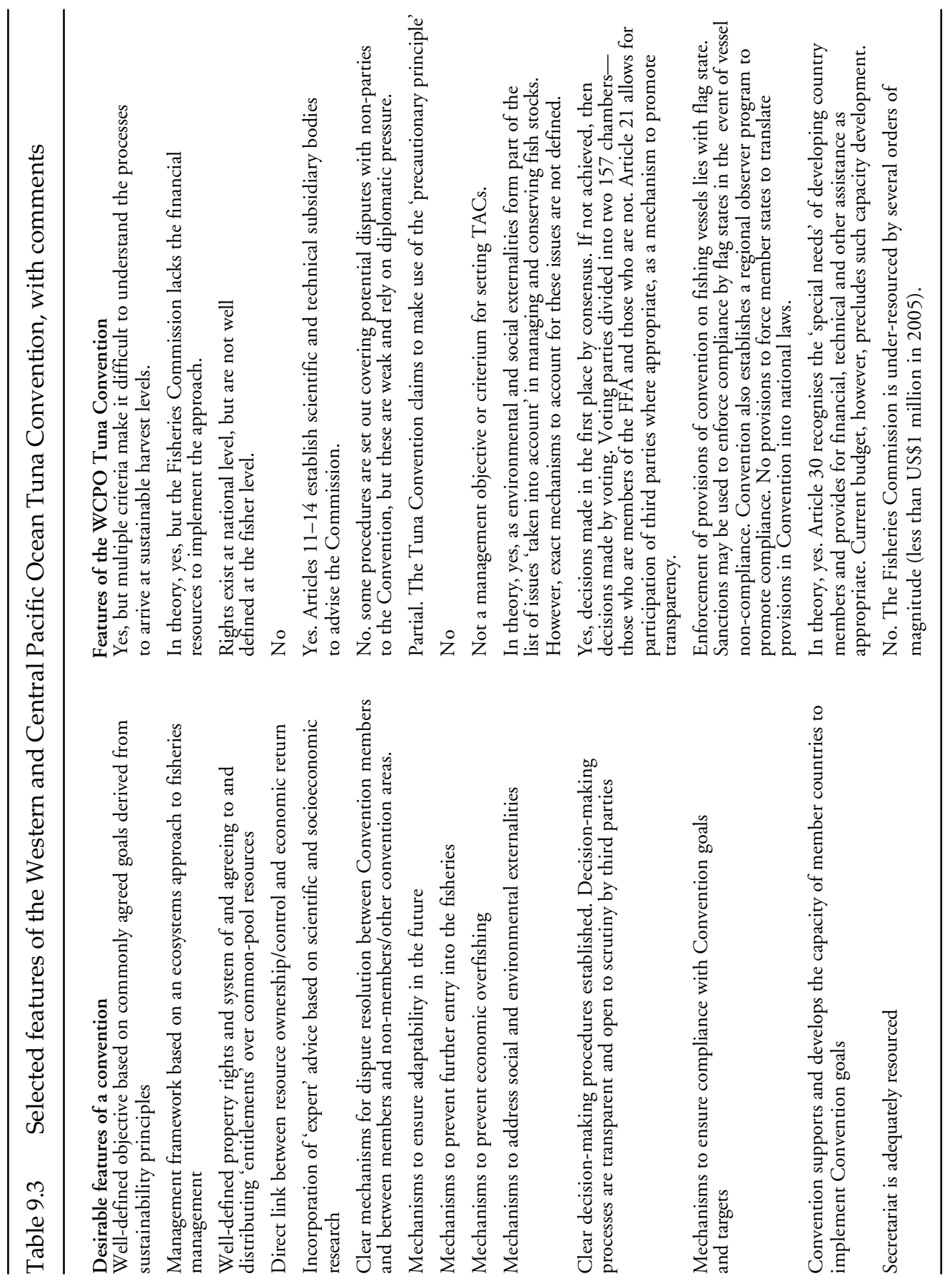


effort within the region. To assist, the Fisheries Commission is to be served by a subsidiary scientific committee and a technical compliance committee. Crucially, however, the setting of total allowable catches to maximise the economic yield or surplus from fishing is not a criterium of the Tuna Convention. The allocation of effort or fish after setting of the total allowable catch is to be made by consensus by signatories to the Tuna Convention.

The effectiveness of the Fisheries Commission is limited by the political will of the member countries and the economic resources that they make available to carry out its mandate. It will be another organisation-along with the Secretariat of the South Pacific Community, located in New Caledonia, and the Forum Fisheries Agency, based in the Solomon Islands-that will provide support for fisheries management. It is not clear how responsibilities will be divided among the organisations, or what coordination there will be between the three organisations, and to what extent, if any, resources will be shared in terms of fisheries management. Thus, although the Forum Fisheries Agency was recently awarded US\$11 million over five years from the Global Environment Facility to support fisheries management in the Pacific (FFA 2005), the budget of less than US\$1 million allocated for the Fisheries Commision's 2005 operations is a matter of concern (Fisheries Commission 2004).

\section{CAPACITY AND GOVERNANCE OF PACIFIC ISLAND COUNTRIES}

The ADB identifies four key principles to good governance: accountability, participation, predictability and transparency (Abbott and Pollard 2004). The inability of Pacific island countries to promote and implement these principles is generally recognised as one of the key factors underscoring poor socioeconomic performance across the Pacific (Abbott and Pollard 2004). Many observers, AusAID included, argue that poor governance and poor institutional quality are major barriers to future development of Pacific island countries (AusAID 2005).

Causes of poor governance lie in a complex mixture of sociocultural and historical factors. Poor institutional performance is also linked to lack of suitably qualified people able (and willing) to address governance issues (Abbott and Pollard 2004). It is most strongly expressed in the low quality of the national public institutions, political instability, weak parliamentary systems, corruption, a politicised public service, and a failure to establish strong institutions of governance (such as auditors or ombudsman). 
Figures 9.2 and 9.3 provide estimates of Pacific island countries' ability to control corruption and a measure of their governments' effectiveness in 2004. For comparison purposes, the estimated levels for Australia and New Zealand are also shown. Both figures place most Pacific island countries in the lower half of world rankings, with some countries, such as the Solomon Islands and Papua New Guinea, listed in the lowest decile of countries. While poor institutions and governance structures are critical factors in explaining the historically poor economic performance of tuna fisheries (Chand et al. 2003; Petersen 2002, 2005; Duncan et al. 1999; Schurman 1998; Hinds 2003), it is difficult to pinpoint any direct causal relationship, other than one of influence. Poor institutions and governance practices are pervasive rather than being specific to tuna management itself, and thus poor management in the fisheries is a symptom rather than a cause of poor economic performance. Moreover, the evidence relating to poor governance, as it directly affects tuna management, tends to be anecdotal although it is possible to make some general observations.

First, the historical approach of setting access conditions and fees is both non-transparent and non-participatory. A secret agreement between national governments makes it extremely difficult for analysts, or the Pacific communities themselves, to identify whether these common-pool tuna resources are being used in the most efficient manner. This is reinforced by the (explicit or implicit) bundling of donor assistance with access-although the provision of aid is of benefit to the Pacific island country in question, it is impossible to determine whether the combination of fees and aid represents the best economic outcome that could be derived from scarce tuna resources (Petersen 2005). This tendency towards 'bundling' is reinforced by the traditional and governance cultures pervasive in the Pacific — that is, the traditional familial links between politicians and their communities and the expectations that these connections will deliver financial benefits.

Governing for sustainability in tuna fisheries adds further layers of complexity. Sustainable governance arrangements for fisheries should, at a minimum, include harvest allocation mechanisms that provide incentives for sustainable fishing practices (Grafton et al. 2005). Chand et al. (2003) also argue that, in addition, fisheries management should include co-management of fisheries between public institutions and fishers, exploitation rates set to ensure longterm sustainability, a coincidence of public and private benefits and incentives 
in exploiting the tuna resources, and cooperation of all parties who have some financial or other interest in the resource (Chand et al. 2003). Clearly, the bilateral arrangements that have served as the main allocative institutions have incorporated few, if any, of these features.

Petersen (2002) also highlights the importance of governance in stimulating private sector participation in the tuna fisheries. Here again, poor governance and inappropriate economic policy settings appear to have failed to stimulate extensive private sector participation in the fisheries. Evidence of this is anecdotal for specific tuna fisheries across the region because the failure to develop a viable private sector is a general, rather than a tuna specific, issue. For example, Gillett et al. (2001) discuss the Papua New Guinea National Fisheries Authority, which, it is claimed, has insufficient internal and external controls, obscure licensing processes subject to manipulation, poor record keeping, mismanagement of trust accounts, and extensive use of influence rather than merit to determine management decisions.

\section{Potential for a resource curse}

Over the longer term, even with the successful implementation of the Tuna Convention, tuna-led development presents more governance challenges to the Pacific island countries. If Pacific island states are able to increase their access fees, this has the potential, in the absence of strong institutions, to generate a 'resource curse' (Auty 2001; Sachs and Warner 2000) for some countries. Pacific island countries require capital to promote their economic development, but in the absence of good governance these funds could contribute to political, economic and social problems that have arisen elsewhere with resource-rich developing countries.

The potential for a resource boom to initiate a 'resource curse' pattern in Pacific states is real. Both Papua New Guinea and Nauru have experienced the resource boom-bust cycle to various degrees, but the potential for a fisheriesinduced resource curse in the Pacific region, and its potential consequences, have been largely ignored.

Resource booms may have both positive and negative consequences on the socioeconomic conditions of resource rich countries. These are often referred to as 'transmission' mechanisms, and usually include phenomena such as declines in the non-resource export sector, crowding out effects, poor decisionmaking at the government level, and a decline in the quality of institutions. Unfortunately, it is possible to discern many of the typical 'transmission' 
Figure 9.2 Measure of the control of corruption for selected Pacific island countries

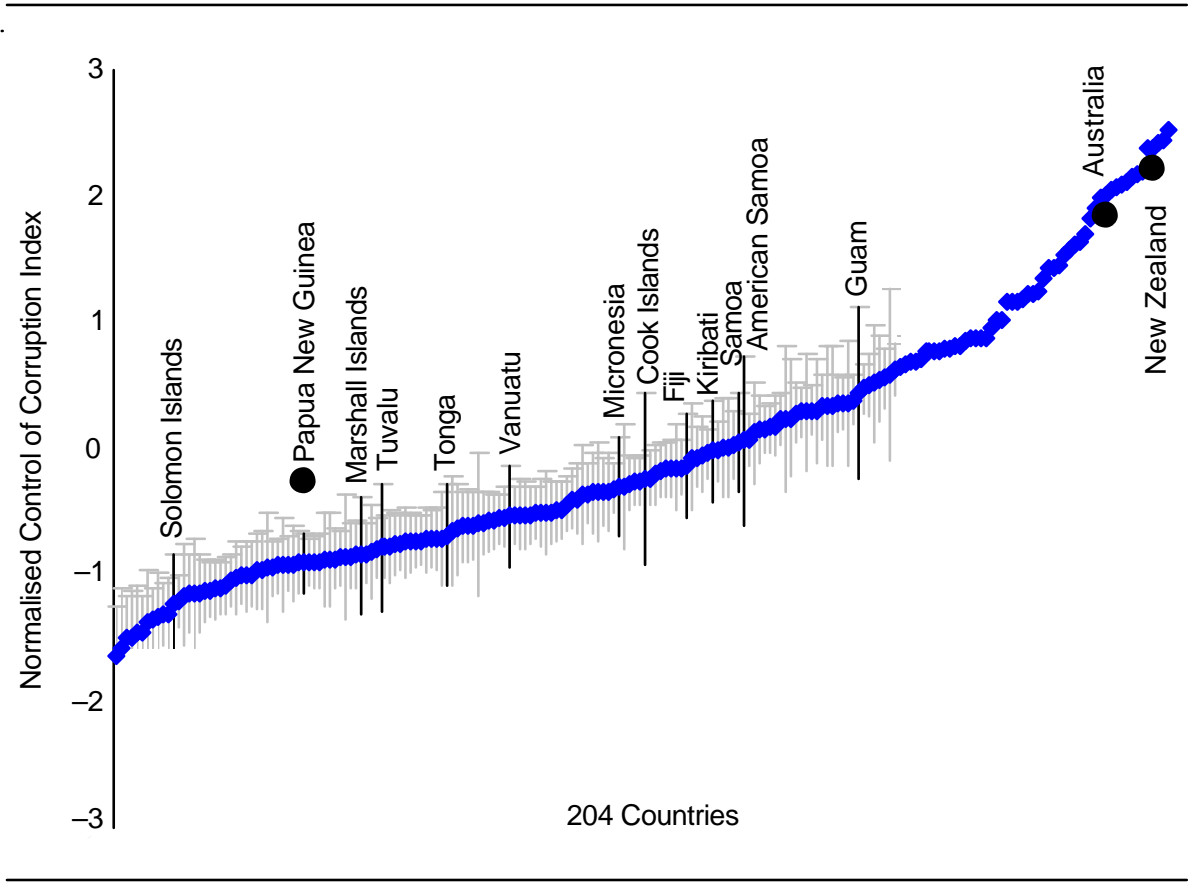

Key: Control of corruption measures perceptions of corruption in terms of using public power for private gain. Chosen comparator is the year 2000. All scores are normalised to be between -3 and 3 where a higher score indicates greater control of corruption. Confidence intervals are denoted by the upper and lower bars for each country.

Source: Authors' calculations and Kaufmann, D., Kraay, A. and Mastruzzi, M., 2005. 'Governance matters IV: governance indicators for 1996-2005', World Bank Economic Review, 18(2):253-87.

dynamics in existence in the Pacific. For example, corruption is key in spreading the impacts of the resource curse, and is also an unfortunate feature of some public institutions in the region.

\section{Avoiding the curse}

A major development focus should be to improve the quality of institutions and governance in the western and central Pacific. In other words, simply ensuring sustainable and economically profitable tuna fisheries is unlikely to be sufficient to bring about sustained development. A successful example of managing fisheries and their revenues is provided by the Falkland Islands 
Figure 9.3 Government effectiveness, 2004

(chosen comparator also shown for selected countries)

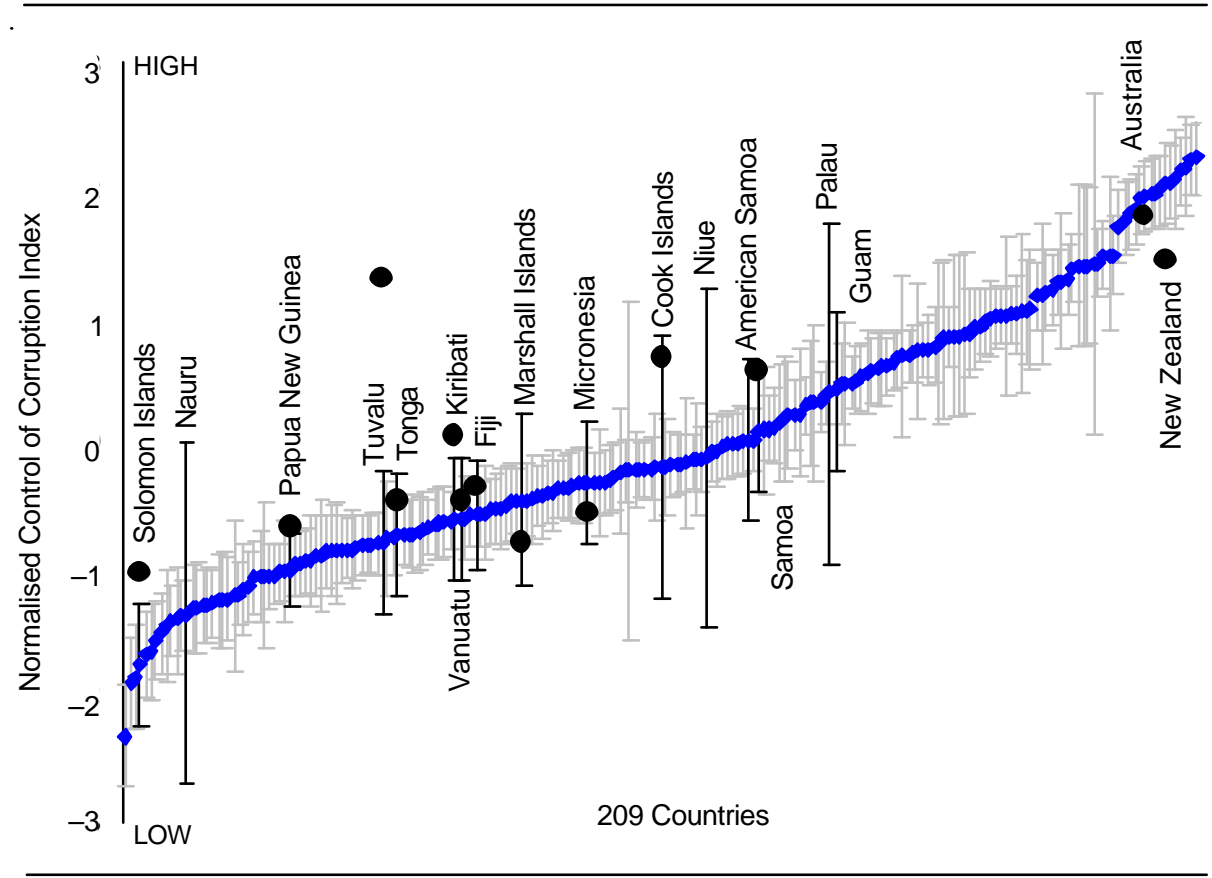

Key: Control of corruption measures perceptions of corruption in terms of using public power for private gain. Chosen comparator is the year 2000. All scores are normalised to be between -3 and 3 where a higher score indicates greater control of corruption. Confidence intervals are denoted by the upper and lower bars for each country.

Source: Kaufmann, D., Kraay, A. and Mastruzzi, M., 2005. Governance Matters IV: governance indicators for 1996-2005, World Bank, Washington, DC.

government, which suggests that very large fisheries revenues, if used wisely, can provide substantial social and economic benefits (Thomas 2002). For instance, the Falkland Islands government has been able to extract substantial access fees while also ensuring monitoring, data collection, surveys and analysis of catch and abundance data to manage the resources sustainably (Falkland Islands Government 2005).

In addition to supporting capacity and institutional development, Pacific island countries and donors could develop 'trust funds' which would be managed separately from other government revenues. The money in the trust funds could be independently managed and audited and any expenditure from the 
fund-beyond a pre-determined level—would be prohibited without an act of parliament or legislation. It would also be possible to specify the sort of expenditures (such as physical infrastructure) that would be permitted from the fund. Trust funds cannot substitute for good quality institutions, but can provide greater transparency in terms of both fishing revenues and expenditures. A trust fund could also provide a sustainable revenue stream for both present and future generations. The successful use of a trust fund by Kiribati for its phosphate royalties - which has generated returns long after mining ceased (Petersen 2005)—suggests that similar funds should be seriously considered by Pacific island countries to deal with fishery access fee revenues.

\section{CONCLUSIONS}

The countries and the territories of the western and central Pacific face formidable challenges to promote their sustainable development. Their shared fisheries resources-and in particular tuna-provide the possibility for 'tuna-led' economic development for some states. This opportunity is, however, constrained by economic overfishing, the inability to deter new entrants and fishing effort, and failed strategies to develop a profitable domestic, but exportorientated, industry. The countries of the region also face problems with corruption and government effectiveness, posing a real risk that fishing revenues will not generate a sustainable flow of income to sustain the region's long-term development.

To address these problems, Pacific island countries and donor nations should consider a twin strategy to maximise the development potential of the region's fishery resources. First, given the potential for cooperation to make every stakeholder better off (including 'distant water fishing nations'), greater effort should be directed to supporting multinational institutions that reduce harvests, increase the transparency of access fee arrangements, and allow for transferability of harvesting rights across countries and vessels. Second, to ensure the most effective use of funds generated from fishing resources, greater attention should be given to increasing capacity in the public sector and improving government effectiveness. This could include, but should not be limited to, developing innovative ways to reduce corruption and prevent the misuse of public revenues by the creation of trust funds for fishing access fees. Both strategies, if successful, increase the possibility of sustained development in the western and central Pacific. 


\section{ACKNOWLEDGMENTS}

We are grateful to the Australian Research Council and the Bureau of Rural Sciences for partial funding of this research. We thank Tom Kompas, Kate Barclay and participants at the International Workshop on Pacific Integration and Regional Governance, Canberra, 8-9 June 2005, for helpful comments and suggestions.

\section{NOTES}

1 Not including aid from France to New Caledonia and French Polynesia, total development assistance is a little less than US $\$ 100$ per capita, although some countries receive substantially more than this amount.

2 'Human Development Ranking' is an index of life expectancy at birth, educational achievement (adult literacy and combined gross primary, secondary and tertiary enrolment) and real per capita GDP.

3 The United Nations Law of the Sea Convention is a universal legal framework designed to manage and conserve marine resources at the international level. It incorporates many different areas of marine and ocean governance, of which the granting of exclusive economic zones to coastal states and the management of fisheries is just one part. It was finalised in 1982 and came into force in 1994.

4 One compliance mechanism is the requirement to participate in a vessel monitoring system (VMS) run by the Forum Fisheries Agency. The vessel monitoring system allows Forum Fishing Agency members to track the location, speed and direction of licensed boats operating in the exclusive economic zones of member countries (van Santen and Muller 2000).

5 The Asian Development Bank cites the following reasons why port development has not been a successful strategy: fleet operators prefer to service vessels in the same ports where they service fish, the later usually lying outside the WCPO Region; volatility in Pacific islands governments' access arrangements; the variable and seasonal nature of resources, which makes use of single ports impractical; poor port and other services; and concerns about law and order in some ports (Duncan et al. 1999).

6 A 'back of the envelope' calculation of the proportion of the resource rent accruing to Pacific island countries is to take the estimated total access fees paid of around US\$60 million in 1999 (Gillett et al. 2001) and divide by the estimated resource rent in 1996 of some US\$160 million (Bertignac et al. 2000). Given the high risks associated with tuna harvesting it would be surprising if Pacific island countries were able to obtain, on a long-term basis, more than half the available resource rent in the form of access fees.

7 As of March 2005, the republic of Korea and Chinese Taipei are the only members that are distant water fishing nations. 


\section{COMMENT}

Tom Kompas

With the decline in fish stocks throughout the world, fisheries management has drawn severe and generally justifiable criticism (Grafton et al. 2005). In this regard it is easy to be critical of fisheries policy in Pacific island states, especially with respect to the management of tuna stocks, since little effective management infrastructure exists and overfishing is widespread. However, Australia, with its own considerable resources, has not performed much better in fisheries management. In the past 10 years the Australian government has committed over US $\$ 80$ million per year to fisheries research and ecologically sustainable development, undertaken substantial buybacks of fishing vessels, implemented detailed scientific fishery management plans that incorporate strong stakeholder involvement, and expanded its system of marine reserves (Grafton et al. 2005; McLoughlin and Findlay 2005). Despite such management strategies, considerable effort creep and total allowable catches that are either too large, or not binding at all, have contributed to a three-fold increase in the number of Australian Commonwealth fisheries classified as overfished in the past 10 years (Caton and McLoughlin 2004). The Eastern Tuna and Billfish Fishery itself is under extreme financial pressure with dramatically falling profits and stocks of tuna and swordfish in particular that are under threat. If Australia is struggling, what hope is there for Pacific island countries? 
The paper by Parris and Grafton (2005) highlights the failure of fisheries management and the impending crisis in Pacific island fisheries, especially with regard to tuna. It is packed with insight, but the story is not a happy one. It is clear that the potential gains from Pacific island cooperation on the management of shared tuna stocks are huge, and especially so now that recent, dramatic increases in catch and declines in catch per unit of effort imply that resource rents are falling, perhaps considerably. A cooperative decrease in fishing effort and a rebuilding of fish stocks will thus result in substantial gains, with the potential for more than double the resource rent from these fisheries (Bertignac et al. 2000). This is the good news. The bad-that Parris and Grafton identify and explain-is that cooperation to this end is highly unlikely, and the failure of the recently formed Convention on the Conservation and Management of Highly Migratory Fish Stocks in the Western and Central Pacific Ocean (Tuna Commission) will do nothing to improve the situation. By Parris and Grafton's account, the Tuna Commission is under-resourced, to say the least, with a budget of US\$1 million in 2005 and no real power or ability to enforce a stock recovery plan in any event. It has also, sadly, failed to incorporate any of the recommendations contained in Chand et al. (2003).

The difficulty is compounded since the measures needed for effective cooperation will also almost always imply relative gains and losses among Pacific island states and, more to the point, stock recovery generates a 'transitional losses' problem that is difficult to overcome in any industry or country. The rebuilding of tuna stocks requires severe cuts in catch now, and for some period of time. In addition, although the larger future resource rents that would accrue from this action would more than compensate for transitional losses-this is the nature of a move to an optimal position where resource rents are maximised-it is difficult to convince those that fish, or those that currently benefit from the fishery, that the process is worth it. Planning horizons in Pacific island nations are undoubtedly as low as they are among fishers in Australia, and no capital market or government agency is likely to fund a stock recovery program with such inherent risk of failure. If transitional losses dominate, cooperation to reduce stocks is all but impossible.

The question then arises is there a benefit to each Pacific island state from going alone in fisheries management? The answer from Parris and Grafton is no. Shared tuna stocks across Pacific island countries imply that cooperation is necessary, at least for tuna, and when it comes to other stocks of fish, local 
governance and management infrastructure is not up to the task, at least for the moment.

Out of exasperation, it is tempting at this point to toss one's hands in the air, and give up. Perhaps 'tuna-mining' is the best approach in this sort of world? But even here, Parris and Grafton are sceptical. They point to the low bargaining power in the Pacific with 'distant water fishing nations'-with consequent low returns in the neighbourhood of 3-4 per cent of the value of total landings by some estimates - and that rents are dissipating in any case. Indeed, even if there are sufficient rents still to be gained Parris and Grafton argue effectively for the presence of a 'resource curse' in these countries, with rents squandered in unproductive uses. If a lack of bargaining power is a problem, what about Pacific nations developing their own tuna fishing industry instead? Parris and Grafton show that under current practice, rates of return for domestic fishers are low if not negative. A domestic industry, as it currently stands, thus cannot hope to extract resource rents with a positive return, much less compete with the gains achieved by 'distant water fishing nations'.

What is the solution? Parris and Grafton argue for greater efforts at reducing harvest through multinational institutions and the transferability of harvesting rights across nations, on the one hand, and the creation of trust funds for fishing access fees to limit the squandering of rents through corruption and misappropriation on the other. All this is good, but what do Pacific states do before this can be accomplished? And can it be accomplished? In the short term, a fish cartel is one possibility, something that collectively extracts more rentals from 'distant water fishing nations', but if Pacific nations can cooperate to this extent surely they can also probably cooperate on protecting tuna stocks as well. Both are unlikely. For now, tuna-mining seems to be the only practical option for any one Pacific island state, extracting the most rents possible before the tuna fishery collapses.

What is needed from Parris and Grafton is a practical plan, something that avoids the tuna-mining trap, a plan that forms a set of policies and incentives that foster and implement the establishment of cooperation among Pacific countries to protect stocks and increase resource rents; one that also overcomes the problem with transitional losses. If properly managed, the Pacific region's tuna stocks can remain highly prized. Indeed, if properly managed, these tuna stocks can all but fully finance the economic development of many Pacific states. The challenge is to find a way to make this happen. 